\title{
Hepatocyte growth factor and carotid intima-media thickness in relation to circulating CD34-positive cell levels
}

\author{
Yuji Shimizu ${ }^{1,2^{*}} \mathbb{D}$, Shimpei Sato ${ }^{1}$, Jun Koyamatsu ${ }^{3}$, Hirotomo Yamanashi ${ }^{3}$, Mako Nagayoshi $^{1}$, Shin-Ya Kawashiri ${ }^{1}$, \\ Keita Inoue ${ }^{1}$, Shoichi Fukui ${ }^{1}$, Hideaki Kondo ${ }^{1}$, Seiko Nakamichi ${ }^{4}$, Yasuhiro Nagata ${ }^{5}$ and Takahiro Maeda ${ }^{1,3}$
}

\begin{abstract}
Background: Hepatocyte growth factor (HGF) may act as a possible biochemical index for vascular damage, although evidence for the association between HGF and carotid intima-media thickness (CIMT) is limited. Since both HGF and circulating CD34-positive cells play an important role in endothelial repair, circulating CD34-positive cell levels may influence the association between HGF and CIMT.

Methods: We conducted a cross-sectional study of 269 elderly Japanese men aged 60-69 years who had undertaken an annual medical checkup from 2014 to 2015.

Results: The median value for circulating CD34-positive cells was 0.93 cells/ $\mu \mathrm{L}$. Among the study population, 135 men showed low circulating CD34-positive cell levels ( $\leq 0.93$ cells/ $/ \mathrm{L}$ ). By multivariable linear regression analysis, HGF was found to be significantly positively associated with CIMT only to participants with low circulating CD34-positive cell levels, with a multi-adjusted $\beta$ of $0.26(p=0.005)$ and $0.002(0.986)$ for low and high circulating CD34-positive cell levels, respectively. In addition, a significant interaction was observed between HGF and circulating CD34-positive cell levels (low and high) on CIMT (multivariable $p$ value of 0.049). A positive association exists between HGF and CIMT in elderly Japanese men, limited to participants with low circulating CD34-positive cell levels.

Conclusion: A positive association exists between HGF and CIMT in community-dwelling elderly Japanese men, which is limited to participants with low numbers of circulating CD34-positive cells. Our findings indicate that circulating CD34-positive cell levels could determine the influence of HGF on CIMT in elderly Japanese men.
\end{abstract}

Keywords: CD34-positive cell, CIMT, Endothelial repair, HGF, Elderly men

\section{Background}

Hepatocyte growth factor (HGF) elicits beneficial effects of endothelial and tissue repair following endothelial injury since it demonstrates cytoprotective and angiogenic activity [1-3] and plays an important role in tissue regeneration [4]. Serum HGF may act as an indicator of vascular endothelial disturbance since HGF levels are elevated in participants demonstrating such a state $[5,6]$. HGF also plays a crucial role in inducing endothelial

\footnotetext{
* Correspondence: shimizuyuji@nagasaki-u.ac.jp

${ }^{1}$ Department of Community Medicine, Nagasaki University Graduate School of Biomedical Sciences, Nagasaki-shi, Sakamoto 1-12-4, Nagasaki 852-8523, Japan

2Department of Cardiovascular Disease Prevention, Osaka Center for Cancer and Cardiovascular Disease Prevention, Osaka, Japan

Full list of author information is available at the end of the article
}

progenitor cell activity such as CD34-positive cell migration and proliferation [7-9]. Since CD34-positive cells have been reported to contribute to endothelial repair [10], the status of circulating CD34-positive cells could influence the effects of HGF-mediated endothelial repair.

On the other hand, as with HGF, platelets have also been shown to play an important role in vascular endothelial repair in conjunction with circulating CD34positive cells [11-13]. Our previous study found that platelet count is positively associated with hypertension in participants with low, but not high, circulating CD34positive cell levels [14]. Since hypertension and endothelial dysfunction have a bidirectional relationship [14-18], circulating CD34-positive cell levels may influence the association between HGF and atherosclerosis.

(c) The Author(s). 2018 Open Access This article is distributed under the terms of the Creative Commons Attribution 4.0 International License (http://creativecommons.org/licenses/by/4.0/), which permits unrestricted use, distribution, and reproduction in any medium, provided you give appropriate credit to the original author(s) and the source, provide a link to the Creative Commons license, and indicate if changes were made. The Creative Commons Public Domain Dedication waiver (http://creativecommons.org/publicdomain/zero/1.0/) applies to the data made available in this article, unless otherwise stated. 
To clarify these associations, we conducted a crosssectional study of Japanese elderly men aged 60-69 years who had taken a general health checkup from 2014 to 2015.

\section{Methods}

\section{Study population}

The total number of male residents of Goto city aged 60-69 (estimated by the National Institute of Population and Social Security Research in March 2013) was 3264 in 2015 [19]. The study population comprised 276 male residents aged 60-69 years from the Goto Islands located in the western part of Japan, who underwent an annual medical checkup in 2014 and 2015 as recommended by the Japanese Government. Those without data for CD34-positive cells $(n=2)$, HGF $(n=3)$, IMT $(n=1)$, or blood $(n=1)$ were excluded from the study population. The remaining patients, 269 men with a mean age of 65.4 years (standard deviation (SD), 2.6; range 60-69), were enrolled in the study.

\section{Data collection and laboratory measurements}

Trained interviewers obtained information on medical history. Current drinker ( $\geq 69 \mathrm{~g} /$ week) and current smoker were defined as drinker and smoker.

Body weight and height were measured with an automatic body composition analyzer (BF-220; Tanita, Tokyo, Japan), and body mass index (BMI; $\mathrm{kg} / \mathrm{m}^{2}$ ) was calculated.

Systolic and diastolic blood pressures of the right arm were measured after at least $5 \mathrm{~min}$ of rest in a sitting position with a blood pressure measuring device (HEM907; Omron, Kyoto, Japan) and recorded by a trained observer.

Fasting blood samples were collected in a heparin sodium tube, EDTA-2K tube, and a siliconized tube. Fresh samples (within $24 \mathrm{~h}$ from drawing) from the heparin sodium tube were used to determine the number of CD34-positive cells. BD (Beckton Dickinson Biosciences) Trucount $^{\text {Tm }}$ technology, an accurate and reproducible single platform assay cited in the International Society of Hematotherapy and Graft Engineering (ISHAGE) guidelines [20] and supported by automated software on the BD FACSCant ${ }^{\mathrm{m}}$ II system, was used to measure the number of circulating CD34-positive cells.

To measure HGF, serum samples were diluted fourfold with specific Bio-Plex sample diluents. HGF concentration was determined using a fluorescent bead-based immunosorbent assay on a suspension array. This method is recommended by the International Committee for Standardization in Hematology.

Samples from the EDTA-2K tube were used to measure white blood cell count using an automated procedure at SRL, Inc. (Tokyo, Japan). Serum triglycerides
(TG), serum high-density lipoprotein cholesterol (HDLc), serum $\gamma$-glutamyltranspeptidase ( $\gamma$-GTP), hemoglobin $\mathrm{A} 1 \mathrm{c}\left(\mathrm{HbA}_{1 \mathrm{C}}\right)$, and serum creatinine were measured using standard laboratory procedures at SRL, Inc. (Tokyo, Japan). Glomerular filtration rate (GFR) was estimated by using an established method recently proposed by a working group of the Japanese Chronic Kidney Disease Initiative [21]. According to this adaptation, GFR $\left(\mathrm{ml} / \mathrm{min} / 1.73 \mathrm{~m}^{2}\right)=194 \times($ serum creatinine (enzyme method) $)^{-1.094} \times(\text { age })^{-0.287}$.

Measurement of carotid intima-media thickness (CIMT) by ultrasonography of the left and right carotid arteries was performed by an experienced vascular technician using a LOGIQ Book XP with a $10-\mathrm{MHz}$ transducer (GE Healthcare, Milwaukee, WI, USA). Mean values for the left and right common CIMT were calculated using automated digital edge-detection software (Intimascope; MediaCross, Tokyo, Japan), with the protocol described in detail elsewhere [22]. Intimascope is an innovative software developed for CIMT measurement to minimize measurement errors. This software makes it possible to recognize automatically the edges of the internal and external membranes of the blood vessels and also to determine automatically the distance at a sub-pixel level (estimated to be $0.01 \mathrm{~mm}$ ) by using a three-dimensional polynomial measurement formula [23]. The reproducibility of CIMT measurements by means of intimascope for our part of the study population $(n=25)$ was shown to be satisfactory: the respective intra-observer variations for CIMT assessed by two examiners were simple correlation coefficients $(r)=0.98$ $(p<0.001)$ and $r=0.97 \quad(p<0.001)$, and the interobserver variation was $r=0.80(p<0.001)$.

\section{Statistical analysis}

Characteristics of the study population in relation to circulating CD34-positive cell levels were expressed as mean \pm standard deviation except for TG, $\gamma$-GTP, and HGF. Since these three factors showed a skewed distribution, the characteristics of the study population were expressed as median [the first quartile, the third quartile], followed by logarithmic transformation. The regression model for mean values was used for calculating $p$ values.

A simple correlation analysis and multiple linear regression analysis of CIMT were conducted with relevant factors adjusted for confounding factors based on circulating CD34-positive cell levels at a median value (0.93 cells $/ \mu \mathrm{L})$. Alcohol consumption and smoking status are well-known factors that affect vascular remodeling. Since $\gamma$-GTP is recognized as a factor that is influenced by alcohol consumption, and WBC as a factor that is influenced by smoking status [24], we added $\gamma$-GTP and $\mathrm{WBC}$ as the confounding factors to the present analysis 
instead of using alcohol consumption and smoking status directly as was done in a previous study of ours [25]. For the multiple linear regression analysis, adjustments were made for age, systolic blood pressure $(\mathrm{mmHg})$, BMI $\left(\mathrm{kg} / \mathrm{m}^{2}\right)$, TG $(\mathrm{mg} / \mathrm{dL})$, HDLc $(\mathrm{mg} / \mathrm{dL}), \gamma$-GTP (IU/L), HbAlc (\%), GFR $\left(\mathrm{mL} / \mathrm{min} / 1.73 \mathrm{~m}^{2}\right)$, and WBC (cells $/ \mu \mathrm{L})$.

Since bone marrow-derived endothelial progenitor cells such as CD34-positive cells have been reported to play an important role in maintaining the vascular endothelium [26, 27], and the level of circulating CD34positive cells may serve as a direct indicator of vascular maintenance activity $[14,15,28,29]$, we also evaluated the association between HGF and CIMT, stratified by circulating CD34-positive cell levels [low $(<0.93$ cells $/ \mu \mathrm{L})$ and high $(\geq 0.93$ cells $/ \mu \mathrm{L})]$.

To evaluate the impact of HGF levels [median value $(301.0 \mathrm{pg} / \mathrm{mL})]$ and circulating CD34-positive cell levels [median value $(0.93$ cells $/ \mu \mathrm{L})$ ] on CIMT, we also created and investigated relevant crosstabs.

All statistical analyses were performed with SAS system for Windows (version 9.4: SAS Inc., Cary, NC). Values of $p<0.05$ were regarded as being statistically significant.

\section{Results}

Among the study population, 135 participants were categorized as having low CD34-positive cell levels $(\leq 0.93$ cells $/ \mu \mathrm{L})$, and 134 participants were categorized as having high levels $(>0.93$ cells $/ \mu \mathrm{L})$.

\section{Characteristics of the study population}

Characteristics of the study population based on circulating CD34-positive cell levels are shown in Table 1. Participants with high CD34-positive cell levels show significantly higher values for BMI, TG, and WBC.

\section{Association between HGF and CIMT in relation to circulating CD34-positive cell levels}

Table 2 shows a simple correlation analysis of CIMT and other variables. For the total participants, HGF was significantly positively associated with CIMT. This association was limited to participants with low CD34-positive cell levels, with essentially the same associations seen from a simple linear regression analysis (Fig. 1). After further adjustment for possible confounding factors, for total participants even the association became non-significant value, for participants with low and high CD34-positive cell levels, these associations remained unchanged (Table 3).
Effects of modification of circulating CD34-positive cell levels on the association between HGF and CIMT

As the positive association between HGF and CIMT was observed only in participants with low circulating CD34positive cell levels, we tested the effect of differing CD34-positive cell levels (low and high) on the slope of HGF and CIMT and found significant values using both a simple $(p=0.011)$ and multivariable linear model $(p=0.049)$.

\section{Mean values of carotid intima-media thickness by HGF levels and CD34-positive cell levels}

Among the participants with lower circulating CD34positive cell levels than those of the reference group with low HGF levels, significantly higher values for CIMT were observed for participants with high HGF levels, but not for those with high circulating CD34-positive cell levels. No significant differences in CIMT between participants with high and low circulating CD34-positive cell levels were observed for participants with either high or low HGF levels (Table 4).

\section{Discussion}

The major finding of the present study is a significant positive association between HGF and CIMT in community-dwelling elderly Japanese men aged 6069 years, limited to participants with low circulating CD34-positive cells.

A previous study of 317 community participants aged over 50 reported that those with higher levels of HGF show significantly higher CIMT values than those with lower values $(8.2 \pm 1.2 \mathrm{~mm}$ and $7.8 \pm 1.4 \mathrm{~mm}, p<0.01$, respectively) [30]. Our results showing a significant positive association between HGF and CIMT by simple correlation analysis in total participants are compatible with the aforementioned study.

We also found further evidence that this positive association is limited to participants with low circulating CD34-positive cell levels.

Serum HGF levels were elevated in participants with a disturbance in vascular endothelial cells, indicating that HGF could act as an indicator of vascular endothelial disturbance $[5,6]$. Since HGF has both cytoprotective and angiogenic activities [1-3] and plays an important role in tissue regeneration [4], HGF demonstrates beneficial effects of endothelial and tissue repair following vascular endothelial injury.

In addition, in the bone marrow microenvironment, HGF is known as a polyfunctional cytokine that is produced by human bone marrow stromal cells and directory or indirectly promotes proliferation, adhesion, and survival of human CD34-positive cells [9]. CD34positive cells have been reported to contribute to endothelial repair [10, 14], and HGF promotes endothelial 
Table 1 Characteristics of the study population based on CD34-positive cell levels

\begin{tabular}{|c|c|c|c|}
\hline & $\begin{array}{l}\text { Low CD34-positive cells } \\
\text { ( } \leq 0.93 \text { cells/ } \mu \mathrm{L})\end{array}$ & $\begin{array}{l}\text { High CD34-positive cells } \\
\text { (>0.93 cells } / \mu \mathrm{L})\end{array}$ & $p$ \\
\hline No. of participants & 135 & 134 & \\
\hline Age, years & $65.5 \pm 2.6$ & $65.2 \pm 2.6$ & 0.378 \\
\hline Systolic blood pressure, $\mathrm{mmHg}$ & $136 \pm 17$ & $137 \pm 18$ & 0.665 \\
\hline Diastolic blood pressure, $\mathrm{mmHg}$ & $84 \pm 12$ & $85 \pm 11$ & 0.513 \\
\hline Drinker, \% & 23.0 & 23.1 & 0.974 \\
\hline Smoker, \% & 16.3 & 16.4 & 0.979 \\
\hline Body mass index (BMI), $\mathrm{kg} / \mathrm{m}^{2}$ & $23.1 \pm 3.0$ & $24.0 \pm 2.8$ & 0.014 \\
\hline Serum triglycerides $(\mathrm{TG}), \mathrm{mg} / \mathrm{dL}$ & $89[66-111]^{a}$ & $110[72-138]^{a}$ & $0.028^{b}$ \\
\hline Serum HDL-cholesterol (HDLc), mg/dL & $57 \pm 14$ & $57 \pm 14$ & 0.744 \\
\hline Serum $\gamma$-glutamyltranspeptidase ( $\gamma$-GTP), IU/L & $31[20-58]^{a}$ & $35[23-50]^{a}$ & $0.379^{b}$ \\
\hline Hemoglobin A1c (HbA1c), \% & $5.6 \pm 0.7$ & $5.8 \pm 0.7$ & 0.168 \\
\hline Serum creatinine, mg/dL & $0.82 \pm 0.14$ & $0.85 \pm 0.15$ & 0.065 \\
\hline Glomerular filtration rate (GFR), $\mathrm{mL} / \mathrm{min} / 1.73 \mathrm{~m}^{2}$ & $75.0 \pm 14.4$ & $71.8 \pm 12.6$ & 0.054 \\
\hline Hepatocyte growth factor (HGF), pg/mL & $285.6[215.8-416.9]^{a}$ & $308.1[231.6-429.2]^{a}$ & $0.325^{b}$ \\
\hline White blood cell count (WBC), cells/ $\mu \mathrm{L}$ & $5325 \pm 1460$ & $6217 \pm 1348$ & $<0.001$ \\
\hline Carotid intima-media thickness (CIMT), mm & $0.70 \pm 0.12$ & $0.69 \pm 0.13$ & 0.881 \\
\hline
\end{tabular}

Values are mean \pm standard deviation

a Values are median [the first quartile, the third quartile]. Regression model for mean values was used for determining $p$ values

${ }^{b}$ Logarithmic transformation was used for evaluating $p$

cell differentiation and increases endothelial progenitor cell migration and proliferation [7, 8]. Both HGF and CD34-positive cells may be positively associated with vascular damage. In fact, these two factors are observed in human atherosclerotic lesions [31-33].

However, increased numbers of circulating CD34positive cells are associated with a decrease in the extent of subclinical atherosclerosis in asymptomatic men [34], while the number of total risk factors for carotid atherosclerosis with high levels of HGF is significantly greater compared to low HGF among community-dwelling participants [30]. This paradoxical phenomenon between HGF and circulating CD34-positive cell count on atherosclerosis may result from a consumptive reduction of circulating CD34-positive cells. When the endothelium sustains damage, both HGF production and circulating CD34-positive cells become elevated. However, if the endothelial disturbance is severe, a large proportion of CD34-positive cells become mature cells (CD34-negative cells) by differentiating into foam cells and endothelial cells [11], resulting in a low level of circulating CD34positive cells remaining. Therefore, high HGF with low

Table 2 Simple correlation analysis of carotid intima-media thickness (CIMT) and other variables

\begin{tabular}{|c|c|c|c|c|c|c|}
\hline & \multicolumn{2}{|c|}{ Total subjects } & \multicolumn{2}{|c|}{ Low CD34-positive cells ( $\leq 0.93$ cells/ $\mu \mathrm{L}$ ) } & \multicolumn{2}{|c|}{ High CD34-positive cells (>0.93 cells/ $\mu \mathrm{L}$ ) } \\
\hline & $r$ & $p$ & $r$ & $p$ & $r$ & $p$ \\
\hline No. of participants & 269 & & 135 & & 134 & \\
\hline Age & 0.17 & 0.005 & 0.13 & 0.141 & 0.21 & 0.013 \\
\hline Systolic blood pressure & 0.14 & 0.023 & 0.17 & 0.047 & 0.11 & 0.212 \\
\hline Body mass index (BMI) & 0.01 & 0.810 & 0.05 & 0.592 & -0.01 & 0.864 \\
\hline Serum triglycerides (TG) & -0.01 & 0.874 & 0.01 & 0.865 & -0.03 & 0.752 \\
\hline Serum HDL-cholesterol (HDLC) & -0.03 & 0.593 & -0.13 & 0.125 & 0.06 & 0.480 \\
\hline Y-Glutamyltranspeptidase ( $\gamma$-GTP) & 0.04 & 0.517 & -0.03 & 0.691 & 0.12 & 0.179 \\
\hline Hemoglobin A1c (HbA1c) & -0.003 & 0.966 & 0.02 & 0.781 & -0.03 & 0.758 \\
\hline Glomerular filtration rate (GFR) & 0.07 & 0.255 & 0.10 & 0.243 & 0.03 & 0.697 \\
\hline White blood cell count (WBC) & 0.11 & 0.086 & 0.17 & 0.051 & 0.05 & 0.525 \\
\hline Hepatocyte growth factor (HGF) & 0.15 & 0.011 & 0.31 & $<0.001$ & 0.01 & 0.892 \\
\hline
\end{tabular}

TG, $\gamma$-GTP, and HGF are calculated in logarithm values 

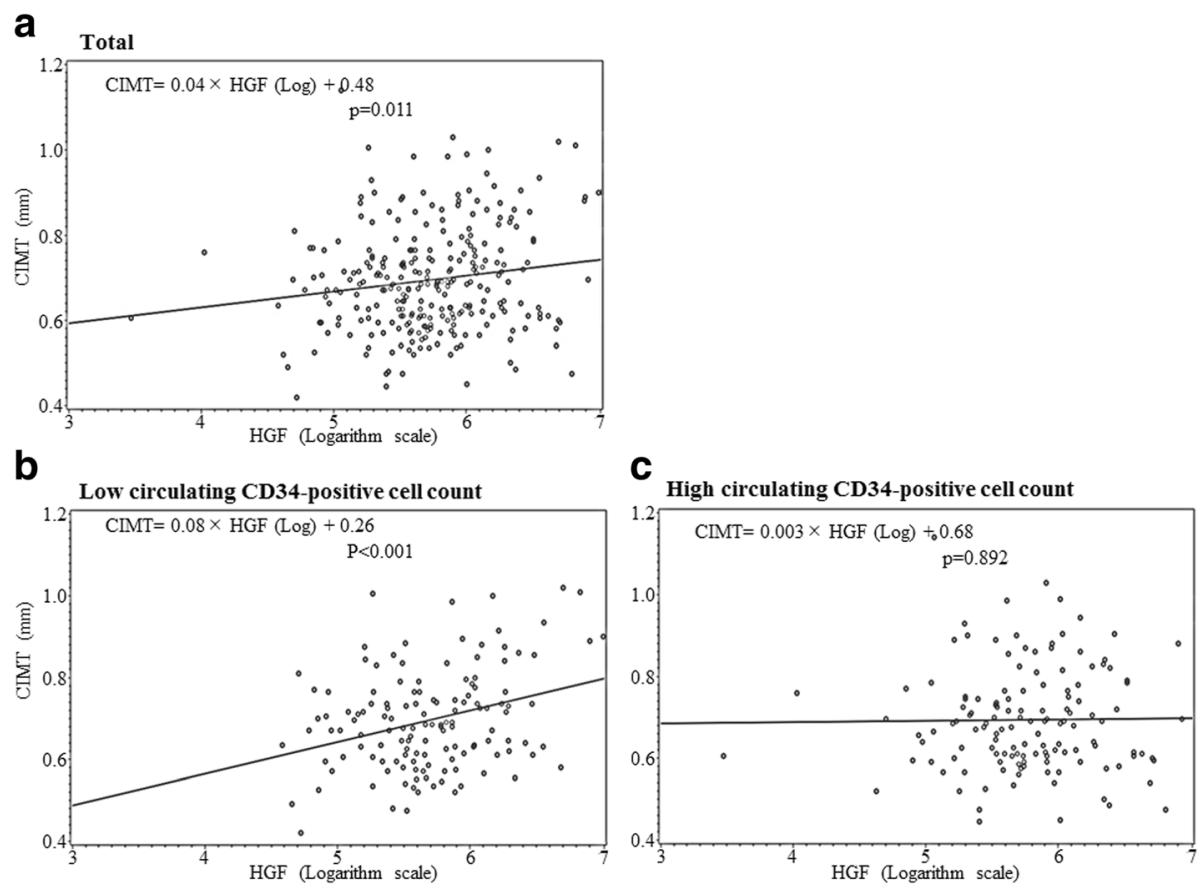

Fig. 1 Scatter plot of hepatocyte growth factor (HGF) and carotid intima-media thickness (CIMT) for participants with a total, b low circulating CD34-positive cells ( $\leq 0.93$ cells/ $\mu \mathrm{L}$ ), and $\mathbf{c}$ high circulating CD34-positive cells (>0.93 cells/ $\mu \mathrm{L}$ )

levels of circulating CD34-positive cells may indicate the presence of aggressive endothelial repair leading to atherosclerosis, while higher HGF along with high levels of circulating CD34-positive cells may indicate the presence of sufficient endothelial repair since no evidence of consumptive reduction of CD34-positive cells is observed. Furthermore, our crosstab analysis showed no statistically significant differences in CIMT values between high and low circulating CD34-positive cell levels, whether in participants with low or high HGF levels.
These findings also support our hypothesis that increased productivity and consumptive reduction may determine the circulating CD34-positive cell count for subjects with active vascular remodeling. This hypothesis is based on the notion that because consumptive reduction of CD34-positive cells followed by increased production of these cells might constitute a strong confounding factor for the association between CIMT and circulating CD34-positive cells among participants with high HGF levels, while no aggressive endothelial

Table 3 Multiple linear regression analysis of carotid intima-media thickness (CIMT)

\begin{tabular}{|c|c|c|c|c|c|c|c|c|c|}
\hline & \multicolumn{3}{|c|}{ Total subjects } & \multicolumn{3}{|c|}{ Low CD34-positive cells ( $\leq 0.93$ cells $/ \mu \mathrm{L}$ ) } & \multicolumn{3}{|c|}{ High CD34-positive cells (>0.93 cells/ $\mu \mathrm{L}$ ) } \\
\hline & B & $\beta$ & p & B & $\beta$ & $p$ & B & $\beta$ & $p$ \\
\hline No. of participants & 269 & & & 135 & & & 134 & & \\
\hline Age & 0.01 & 0.16 & 0.007 & 0.004 & 0.08 & 0.344 & 0.01 & 0.23 & 0.013 \\
\hline Systolic blood pressure & 0.0009 & 0.12 & 0.047 & 0.001 & 0.17 & 0.072 & 0.0005 & 0.07 & 0.449 \\
\hline Body mass index (BMI) & -0.0006 & -0.01 & 0.829 & 0.001 & 0.03 & 0.762 & -0.0009 & -0.02 & 0.844 \\
\hline Serum triglycerides (TG) & -0.0004 & -0.05 & 0.528 & -0.001 & -0.07 & 0.503 & 0.0002 & 0.03 & 0.804 \\
\hline Serum HDL-cholesterol (HDLC) & -0.02 & -0.07 & 0.361 & -0.02 & -0.06 & 0.574 & -0.01 & -0.06 & 0.555 \\
\hline$\gamma$-Glutamyltranspeptidase ( $\gamma$-GTP) & 0.01 & 0.03 & 0.669 & -0.02 & -0.09 & 0.367 & 0.02 & 0.11 & 0.231 \\
\hline Hemoglobin A1c (HbA1c) & -0.01 & -0.04 & 0.517 & -0.02 & -0.08 & 0.363 & -0.01 & -0.05 & 0.617 \\
\hline Glomerular filtration rate (GFR) & 0.0005 & 0.06 & 0.342 & 0.001 & 0.06 & 0.490 & 0.0003 & 0.03 & 0.749 \\
\hline White blood cell count (WBC) & 0.00001 & 0.10 & 0.145 & 0.00001 & 0.07 & 0.475 & 0.00001 & 0.13 & 0.194 \\
\hline Hepatocyte growth factor (HGF) & 0.03 & 0.12 & 0.070 & 0.06 & 0.26 & 0.005 & 0.0004 & 0.002 & 0.986 \\
\hline
\end{tabular}

All listed variables have been entered in multiple linear regression analysis. TG, $\gamma$-GTP, and HGF are calculated in logarithm values B parameter estimate, $\beta$ standardized parameter estimate 
Table 4 Mean values of carotid intima-media thickness (CIMT) in terms of hepatocyte growth factor (HGF) levels and CD34-positive cell levels

\begin{tabular}{llll}
\hline & $\begin{array}{l}\text { Low CD34-positive } \\
\text { cells }(\leq 0.93 \text { cells } / \mu \mathrm{L})\end{array}$ & $\begin{array}{l}\text { High CD34-positive } \\
\text { cells }(>0.93 \text { cells } / \mu \mathrm{L})\end{array}$ & $p$ \\
\hline $\begin{array}{l}\text { Low HGF } \\
(\leq 301.0 \mathrm{pg} / \mathrm{mL})\end{array}$ & $0.67 \pm 0.11$ & $0.69 \pm 0.13$ & 0.319 \\
$\begin{array}{l}\text { High HGF } \\
(>301.0 \mathrm{pg} / \mathrm{mL})\end{array}$ & $0.73 \pm 0.13$ & $0.70 \pm 0.13$ & 0.201 \\
$p$ & 0.004 & 0.586 & \\
\hline
\end{tabular}

repair that would affect the progression of CIMT is necessary for those with low HGF levels.

Circulating CD34-positive cells have also been revealed to play an important role in vascular endothelial repair in conjunction with platelets [11-13], and platelets are significantly positively associated with hypertension in participants with low, but not high, circulating CD34-positive cell levels [14]. Our present results are supported by these studies since a vicious cycle exists between hypertension and endothelial dysfunction [14-18], and the different associations between circulating CD34-positive cells and platelets and hypertension [14] could be induced by consumptive reduction of the former.

Although the sample used for our study was small, it is the largest sample used to date for a study dealing with circulating CD34-positive cell levels in a general elderly population selected with strict criteria, since the participants were restricted to men in a narrow age range because differences in gender and age can act as strong confounding factors on associations between CD34-positive cells, HGF, and CIMT [25, 35-40]. For this reason, even age was slightly but significantly positively associated with CIMT (simple correlation coefficient $(r)=0.17 p<0.005)$ in our study, while no such associations were observed for logarithm-transformed CD34-positive cells $(r=-0.006, p=0.034)$ and HGF $(r=$ 0.03, $p=0.646$ ).

Potential limitations of this study warrant consideration. Although the level of circulating CD34-positive cells influenced on the association between HGF and CIMT significantly, no data was available with regard to the evaluation of endothelial function. Further analyses that include endothelial function-related data such as flow-mediated dilation (FMD) will be necessary. Additionally, because this was a cross-sectional study, causal relationships were not able to be established.

\section{Conclusions}

In conclusion, a positive association exists between HGF and CIMT in community-dwelling elderly Japanese men, which is limited to participants with low numbers of circulating CD34-positive cells. Our findings indicate that circulating CD34-positive cell levels could determine the influence of HGF on CIMT in elderly Japanese men and can be expected to serve as an effective tool for the clarification of the roles played by HGF and CD34-positive cells in the progression of atherosclerosis.

\section{Abbreviations}

BD: Beckton Dickinson Biosciences; BMI: Body mass index; CIMT: Carotid intima-media thickness; GFR: Glomerular filtration rate; HbA1c: Hemoglobin A1c; HDLc: High-density lipoprotein cholesterol; HGF: Hepatocyte growth factor; ISHAGE: International Society of Hematotherapy and Graft Engineering; TG: Triglycerides; $\gamma$-GTP: $\gamma$-Glutamyltranspeptidase

\section{Acknowledgements}

We are grateful to the staff of Goto city office for their outstanding support.

\section{Funding}

This study was supported by Grants-in-Aid for Scientific Research from the Japan Society for the Promotion of Science (No. 15K07243, No. 17H03740, No. 18K06448).

\section{Availability of data and materials}

The datasets generated and/or analyzed during the current study are not publicly available due to ethical consideration but are available from the corresponding author on reasonable request.

\section{Authors' contributions}

YS designed the study and performed the statistical analyses, interpreted the data, drafted the manuscript, and revised it. SS, JK, HY, MN, SK, SN, KI, SF, and $\mathrm{HK}$ assisted with the design of the study, were involved in the data collection, and checked the manuscript. YN and TM participated in the study concept and checked the manuscript. TM was the general coordinator and also designed the study. All authors read and approved the final manuscript.

\section{Ethics approval and consent to participate}

All procedures performed in the studies involving human participants were in accordance with the ethical standards of the institution research committee and with the 1964 Helsinki Declaration and its later amendments for comparable ethical standards. The Ethics Committee for Human Use of Nagasaki University obtained ethical approval. This study was approved by the Ethics Committee of Nagasaki University Graduate School of Biomedical Sciences (project registration number 14051404). Written consent forms were available in Japanese to ensure a comprehensive understanding of the study objectives, and informed consent was provided by the participants.

\section{Competing interests}

The authors declare that they have no competing interests.

\section{Publisher's Note}

Springer Nature remains neutral with regard to jurisdictional claims in published maps and institutional affiliations.

\section{Author details}

${ }^{1}$ Department of Community Medicine, Nagasaki University Graduate School of Biomedical Sciences, Nagasaki-shi, Sakamoto 1-12-4, Nagasaki 852-8523, Japan. ${ }^{2}$ Department of Cardiovascular Disease Prevention, Osaka Center for Cancer and Cardiovascular Disease Prevention, Osaka, Japan. ${ }^{3}$ Department of Island and Community Medicine, Nagasaki University Graduate School of Biomedical Sciences, Nagasaki, Japan. ${ }^{4}$ Department of General Medicine, Nagasaki University Hospital, Nagasaki, Japan. ${ }^{5}$ Center for Comprehensive Community Care Education, Nagasaki University Graduate School of Biomedical Sciences, Nagasaki, Japan. 


\section{Received: 24 January 2018 Accepted: 26 April 2018}

\section{Published online: 03 May 2018}

\section{References}

1. Aoki M, Morishita R, Taniyama Y, Kida I, Moriguchi A, Matsumoto K, et al. Angiogenesis induced by hepatocyte growth factor in noninfarcted myocardium and infarcted myocardium: up-regulation of essential transcription factor for angiogenesis, ets. Gene Ther. 2000;7:417-27.

2. Bussolino F, Di Renzo MF, Ziche M, Bocchietto E, Olivero M, Naldini L, et al. Hepatocyte growth factor is a potent angiogenic factor which stimulates endothelial cell motility and growth. J Cell Biol. 1992;119:629-41.

3. Van Belle E, Witzenbichler B, Chen D, Silver M, Chang L, Schwall R, et al. Potentiated angiogenic effect of scatter factor/hepatocyte growth factor via induction of vascular endothelial growth factor: the case for paracrine amplification of angiogenesis. Circulation. 1998;97:381-90.

4. Matsumoto K, Nakamura T. Hepatocyte growth factor (HGF) as a tissue organizer for organogenesis and regeneration. Biochem Biophys Res Commun. 1997;239:639-44.

5. Nishimura M, Ushiyama M, Ohtsuka K, Nishida M, Inoue N, Matsumuro A, et al. Serum hepatocyte growth factor as a possible indicator of vascular lesions. J Clin Endocrinol Metab. 1999;84:2475-80.

6. Nakamura S, Moriguchi A, Morishita R, Aoki M, Yo Y, Hayashi S, et al. A novel vascular modulator, hepatocyte growth factor (HGF), as a potential index of the severity of hypertension. Biochem Biophys Res Commun. 1998;242:238-43.

7. Zhu G, Huang L, Song M, Yu Z, Wu X, Zhao X, et al. Over-expression of hepatocyte growth factor in smooth muscle cells regulates endothelial progenitor cells differentiation, migration and proliferation. Int J Cardiol. 2010;138:70-80.

8. Yang ZJ, Xu SL, Chen B, Zhang SL, Zhang YL, Wei W, et al. Hepatocyte growth factor plays a critical role in the regulation of cytokine production and induction of endothelial progenitor cell mobilization: a pilot gene therapy study in patients with coronary heart disease. Clin Exp Pharmacol Physiol. 2009;36:790-6.

9. Weimar IS, Miranda N, Muller EJ, Hekman A, Kerst JM, de Gast GC, et al. Hepatocyte growth factor/scatter factor (HGF/SF) is produced by human bone marrow stromal cells and promotes proliferation, adhesion and survival of human hematopoietic progenitor cells (CD34+). Exp Hematol. 1998:26:885-94.

10. Majka M, Janowska-Wieczorek A, Ratajczak J, Ehrenman K, Pietrzkowski Z, Kowalska MA, et al. Numerous growth factors, cytokines, and chemokines are secreted by human CD34(+) cells, myeloblasts, erythroblasts, and megakaryoblasts and regulate normal hematopoiesis in an autocrine/ paracrine manner. Blood. 2001;97:3075-85.

11. Daub K, Langer H, Seizer P, Stellos K, May AE, Goyal P, et al. Platelets induce differentiation of human CD34+ progenitor cells into foam cells and endothelial cells. FASEB J. 2006;20:2559-61.

12. Stellos K, Langer H, Daub K, Schoenberger T, Gauss A, Geisler T, et al. Platelet-derived stromal cell-derived factor-1 regulates adhesion and promotes differentiation of human CD34+ cells to endothelial progenitor cells. Circulation. 2008;117:206-15.

13. Seitz G, Boehmler AM, Kanz L, Möhle R. The role of sphingosine 1phosphate receptors in the trafficking of hematopoietic progenitor cells. Ann N Y Acad Sci. 2005;1044:84-9.

14. Shimizu Y, Sato S, Koyamatsu J, Yamanashi H, Nagayoshi M, Kadota K, et al. Platelets and circulating CD34-positive cells as an indicator of the activity of the vicious cycle between hypertension and endothelial dysfunction in elderly Japanese men. Atherosclerosis. 2017;259:26-31.

15. Shimizu Y, Sato S, Koyamatsu J, Yamanashi H, Nagayoshi M, Kadota K, et al. Possible mechanism underlying the association between higher hemoglobin level and hypertension in older Japanese men. Geriatr Gerontol Int. 2017;17:2586-92.

16. Shimizu Y, Kadota $K$, Nakazato M, Noguchi Y, Koyamatsu J, Yamanashi $H$, et al. Hemoglobin as a possible biochemical index of hypertension-induced vascular damage. J Physiol Anthropol. 2016;35:4.

17. Shimizu Y, Nakazato M, Sekita T, Kadota K, Arima K, Yamasaki $\mathrm{H}$, et al. Association between the hemoglobin levels and hypertension in relation to the BMI status in a rural Japanese population: the Nagasaki Islands study. Intern Med. 2014;53:435-40.
18. Shimizu Y, Nakazato M, Sekita T, Kadota K, Yamasaki H, Takamura N, et al. Association between hemoglobin levels and arterial stiffness for general Japanese population in relation to body mass index status: the Nagasaki Islands study. Geriatr Gerontol Int. 2014;14:811-8.

19. National Institute of Population and Social Security Research [Home page on the Internet]. [Cited February 8, 2018] Available from: http://www.ipss.go. jp/pp-shicyoson/j/shicyoson13/3kekka/Municipalities.asp

20. Sutherland DR, Anderson L, Keeney M, Nayar R, Chin-Yee I. The ISHAGE guidelines for CD34+ cell determination by flow cytometry. International Society of Hematotherapy and Graft Engineering. J Hematother. 1996;5:213-26.

21. Imai E, Horio M, Watanabe T, Iseki K, Yamagata K, Hara S, et al. Prevalence of chronic kidney disease in the Japanese general population. Clin Exp Nephrol. 2009;13:621-30.

22. Hara T, Takamura N, Akashi S, Nakazato M, Maeda T, Wada M, et al. Evaluation of clinical markers of atherosclerosis in young and elderly Japanese adults. Clin Chem Lab Med. 2006:44:824-9.

23. Yanase T, Nasu S, Mukuta Y, Shimizu Y, Nishihara T, Okabe T, et al. Evaluation of a new carotid intima-media thickness measurement by Bmode ultrasonography using an innovative measurement software, intimascope. Am J Hypertens. 2006;19:1206-12.

24. Kawada T. Relationships between the smoking status and plasma fibrinogen, white blood cell count and serum C-reactive protein in Japanese workers. Diabetes Metab Syndr. 2015;9:180-2.

25. Shimizu Y, Sato S, Koyamatsu J, Yamanashi H, Nagayoshi M, Kadota K, et al. Possible mechanism underlying the association between height and vascular remodeling in elderly Japanese men. Oncotarget. 2018;9:7749-57.

26. Asahara T, Murohara T, Sullivan A, Silver M, van der Zee R, Li T, et al. Isolation of putative progenitor endothelial cells for angiogenesis. Science. 1997;275:964-7

27. Takahashi T, Kalka C, Masuda H, Chen D, Silver M, Kearney M, et al. Ischemia- and cytokine-induced mobilization of bone marrow-derived endothelial progenitor cells for neovascularization. Nat Med. 1999;5:434-8.

28. Shimizu Y, Sato S, Koyamatsu J, Yamanashi H, Nagayoshi M, Kadota K, et al. Circulating CD34-positive cells, glomerular filtration rate and triglycerides in relation to hypertension. Atherosclerosis. 2015;243:71-6.

29. Shimizu Y, Sato S, Koyamatsu J, Yamanashi H, Nagayoshi M, Kadota K, et al. Association between high-density lipoprotein-cholesterol and hypertension in relation to circulating CD34-positive cell levels. J Physiol Anthropol. 2017;36:26.

30. Yamamoto Y, Kohara K, Tabara Y, Igase M, Nakura J, Miki T. Plasma hepatocyte growth factor and the relationship between risk factors and carotid atherosclerosis. Hypertens Res. 2002;25:661-7.

31. Ma H, Calderon TM, Fallon JT, Berman JW. Hepatocyte growth factor is a survival factor for endothelial cells and is expressed in human atherosclerotic plaques. Atherosclerosis. 2002;164:79-87.

32. Torsney E, Mandal K, Halliday A, Jahangiri M, Xu Q. Characterisation of progenitor cells in human atherosclerotic vessels. Atherosclerosis. 2007;191:259-64.

33. Moreno PR, Purushothaman KR, Fuster V, Echeverri D, Truszczynska H, Sharma SK, et al. Plaque neovascularization is increased in ruptured atherosclerotic lesions of human aorta: implications for plaque vulnerability. Circulation. 2004;110:2032-8.

34. Bielak LF, Horenstein RB, Ryan KA, Sheedy PF, Rumberger JA, Tanner K, et al. Circulating CD34+ cell count is associated with extent of subclinical atherosclerosis in asymptomatic Amish men, independent of 10-year Framingham risk. Clin Med Cardiol. 2009:3:53-60.

35. Coviello AD, Kaplan B, Lakshman KM, Chen T, Singh AB, Bhasin S. Effects of graded doses of testosterone on erythropoiesis in healthy young and older men. J Clin Endocrinol Metab. 2008:93:914-9.

36. Shimizu Y, Sato S, Koyamatsu J, Yamanashi H, Nagayoshi M, Kadota K, et al. Height indicates hematopoietic capacity in elderly Japanese men. Aging (Albany NY). 2016;8:2407-13.

37. Shimizu Y, Sato S, Koyamatsu J, Yamanashi H, Nagayoshi M, Kadota K, et al. Height is an indicator of vascular maintenance capacity in older men. Geriatr Gerontol Int. 2017;17:1729-36.

38. Yamanashi H, Shimizu Y, Koyamatsu J, Nagayoshi M, Kadota K, Tamai M, et al. Circulating CD34-positive cells are associated with handgrip strength in Japanese older men: the Nagasaki Islands study. J Frailty Aging. 2017;6:6-11. 
39. Shimizu Y, Nakazato M, Sato S, Nagayoshi M, Kadota K, Noguchi Y, et al. Hepatocyte growth factor as an indicator of reduced handgrip strength among non-overweight hypertensive elderly men. Arch Inflamm. 2016;1:3.

40. Kadota K, Takamura N, Aoyagi K, Yamasaki H, Usa T, Nakazato M, et al. Availability of cardio-ankle vascular index (CAVI) as a screening tool for atherosclerosis. Circ J. 2008;72:304-8.

Ready to submit your research? Choose BMC and benefit from:

- fast, convenient online submission

- thorough peer review by experienced researchers in your field

- rapid publication on acceptance

- support for research data, including large and complex data types

- gold Open Access which fosters wider collaboration and increased citations

- maximum visibility for your research: over $100 \mathrm{M}$ website views per year 